\title{
Growing Motivation Learning of Matrix Through Peer Tutoring Learning
}

\author{
Dila Umnia Soray a \\ Electrical Engineering Department \\ Universitas Negeri Malang (UM) \\ Malang, Indonesia \\ dila.umnia.ft@um.ac.id
}

\begin{abstract}
The research aims to describe the level of student motivation in learning matrix through peer tutoring learning. The concept of a matrix is very important in the field of informatics engineering because it is necessary to create computer programs, so the student must be serious and careful in understanding the matrix material. With a fun learning model, learning motivation will grow and students become easier to absorb the material. Given the importance of motivation to learn and achievement of students, lecturers should al ways innovate in the method and model of teaching. One of the innovative learning models that can be applied by lecturers in developing the motivation to learn the mathematics of students is by peer tutoring learning. The subjects of the study were all students of S1 Program of Informatics Engineering Education, State University of Malang Year 2016 Class which amounted to 4 classes, each offering consists of approximately 30 students. Total subjects of research are as many as $\mathbf{1 2 5}$ students. Data collection techniques using questionnaires with Likert scale $\mathbf{4}$ alternative answers, 1) Strongly disagree, 2) Less agree, 3) Agree, and 4) Strongly agree. A questionnaire created with Google Form feature, distributed and socialized to all offerings. Data analysis using descriptive statistical techniques, score calculations and percentages with the help of software SPSS and Microsoft Excel. The result of research mentioned that $86 \%$ of students are motivated to learn Matrix material by using peer tutoring learning. Intrinsic motivation is $87 \%$, extrinsic motivation is $85 \%$. Coverage of intrinsic motivation indicators, needs $(84 \%)$, interest $(87 \%)$, curiosity $(91 \%)$, and pleasure $(87 \%)$. While extrinsic motivation indicator that is clarity of learning objectives $(80 \%)$ and prize $(89 \%)$.
\end{abstract}

Keywords-peer tutoring, matrix, motivation, vocational

\section{INTRODUCTION}

Mathematics is a compulsory subject as the basis of other courses in engineering, particularly informatics engineering. Mathematics Engineering is one of the compulsory subjects taught in the S1 Program of Informatics Engineering Education, Faculty of Engineering, One of the materials that according to the students need accuracy is the Matrix. The concept of the matrix itself is very important in the field of informatics engineering because it is required in the making of the program. In programming, the matrix is known as Array. An array is a collection of data where each element uses the same type of name and each element is accessed by differentiating its array index. In other words, the array is an indexed variable. The index must be of the type that has a sort, has a succesor and predesor, eg integer, byte, character, and boolean. Seeing the importance of understanding about the concept of the matrix in this field of informatics so that students must be serious and careful in understanding the matrix material that existed in the Mathematics Engineering course.

As we know that all this time, mathematics such as the specter, both for elementary, middle, upper, and college students, because the material demands critical thinking, precision, and thoroughness. Lecturers as mediators of learning must be smart in managing the class, process the media, determine the methods and models of learning, and provoke motivation and the spirit of student learning. Because, with a fun learning model, learning motivation will grow and students become more easily absorb the material according to the level of difficulty of each.

In the learning process, motivation is needed, because students do learning activities one of them with motivation. Barton and Martin define motivation as a force that can move behavior and lead behavioral directions and tend to keep showing the behavior. Djamarah [1] defines motivation as a change of energy in a person characterized by the emergence of feelings, preceded by a response to the purpose. Energy changes in a person are in the form of a real activity of physical activity. Because a person has a specific purpose and activity, then someone has a strong motivation to achieve it with all the efforts he can do to achieve it.

According to Sardirman [2] there are two types of motivation, namely intrinsic motivation and extrinsic motivation. Intrinsic motivation is the motivation that comes from a person without the need for encouragement or stimulation from the outside. While extrinsic motivation is an active motivation because there are stimuli from the outside. Intrinsic motivation includes need, interest, curiosity, and pleasure. Extrinsic motivation includes clarity of learning objectives and gift giving.

In addition to motivation, selection of learning models can also provoke the growth of students extrinsic motivation. There are many cooperative learning models used by lecturers in the learning process that aim to create a pleasant classroom atmosphere. A pleasant learning environment can foster motivation to teach lecturers and student learning. One effective learning model that can be used to learn mathematical techniques is peer tutoring learning. Peer Tutoring Learning is 
one of the interesting learning models and can be used by lecturers in teaching mathematics to students. Peer tutoring means learning student teaching, which is a learning model that requires students to act as teachers (tutors) and other students as students who are taught. Peer tutoring learning model can help facilitate students in understanding Matrix material because that role as a teacher is peers. Students can learn cooperatively, play an active role, and be able to solve problems together. Students have the freedom to ask questions that have not been understood with confidence. Peer tutoring learning embodies the ideals of student centered learning or student-centered learning. The research aims to describe the level of student motivation in learning matrix through peer tutoring learning.

\section{METHOD}

This research is descriptive, aiming to describe the level of student motivation in following learning Matrix material by using peer tutoring learning model which includes intrinsic motivation and extrinsic motivation. Intrinsic motivation consists of several indicators, namely need, interest, curiosity, and pleasure. While extrinsic motivation includes clarity of learning and gift goals. The technique of collecting data using questionnaire technique with research instrument in the form of a questionnaire. A sheet of computer-made questionnaires, through the Google Docs app, consists of 25 statements with 4 alternative answers. An alternative answer questionnaire scale has a grade level: (4) Strongly agree, (3) Agree, (2) Disagree, and (1) Strongly disagree. There are also some statements with alternative answers such as checklists. The grid of the research instrument is complete in Table 1 .

TABLE I. THE GRATING OF THE QUESTIONNAIRE

\begin{tabular}{|c|l|l|l|}
\hline No. & \multicolumn{1}{|c|}{ Indicators } & Positive item & Negative item \\
\hline \multicolumn{3}{|l|}{ Intrinsic Motivation } \\
\hline 1 & Needs & $16,17,23,25$ & 21,22 \\
\hline 2 & Interest & $7,11,13,14$ & 12,15 \\
\hline 3 & Curiosty & $5,6,18$ & 20 \\
\hline 4 & Pleasure & 1,8 & 9 \\
\hline Extrinsic & Motivation & \\
\hline 1 & $\begin{array}{l}\text { Clarity of learning } \\
\text { objectives }\end{array}$ & $2,3,4$ & 10 \\
\hline 2 & Prize & 19,24 & \\
\hline
\end{tabular}

Questionnaires were distributed by using technology, such as the internet, social media, and gadget to all students of S1 Program of Informatics Engineering Education, The year 2016. Respondents are all students of S1 Program of Informatics Engineering Education, Year Force 2016 consisting of 4 classes (Offering A - D) of 125 people. Data of the questionnaire results will be analyzed using the calculation formula score and made the graph. Based on the results of data analysis will know the level of student motivation in following learning material Matrix by using peer tutoring learning model (peer tutoring learning) viewed from 6 indicators divided into two parts, which have been determined. Interpretation of student motivation level data is shown in Table 2.

TABLE II. DATA INTERPRETATION GUIDELINES

\begin{tabular}{|c|c|c|}
\hline No. & Score & Criteria \\
\hline 1 & $85-100$ & Very high \\
\hline 2 & $75-84$ & High \\
\hline 3 & $60-74$ & High enough \\
\hline 4 & $40-59$ & Low \\
\hline 5 & $0-39$ & Very low \\
\hline
\end{tabular}

\section{RESULTS AND DISCUSSION}

Based on research data, it is found that the percentage of student motivation in matrix learning is $86 \%$. The level of student motivation is measured based on 2 indicators, namely intrinsic motivation and extrinsic motivation. The percentage of intrinsic motivation is $87 \%$ and extrinsic motivation is $85 \%$, both of which fall into the very high category.

TABLE III. DATA OF STUdENT Motivation

\begin{tabular}{|c|c|c|c|}
\hline No. & Indicators & $\%$ & Criteria \\
\hline \multicolumn{4}{|c|}{ Intrinsic Motivation } \\
\hline 1 & Needs & 84 & High \\
\hline 2 & Interest & 87 & Very High \\
\hline 3 & Curiosty & 91 & Very High \\
\hline 4 & Pleasure & 87 & Very High \\
\hline \multicolumn{4}{|c|}{ Extrinsic Motivation } \\
\hline 1 & $\begin{array}{l}\text { Clarity of learning } \\
\text { objectives }\end{array}$ & 80 & High \\
\hline 2 & Prize & 89 & Very High \\
\hline
\end{tabular}

\section{A. Intrinsic Motivation}

Sub-indicators of intrinsic motivation include 1) need, 2) interest, 3) curiosity, and 4) pleasure. Based on the research data in Table 3, it is known that the highest percentage is a sense of curiosity with a percentage of $91 \%$. The curiosity shown by the students is demonstrated by the liveliness of asking, discussing, finding solutions to problems, and enthusiastic listening to tutor explanations. Of 125 students, 85 people $(68 \%)$ felt confident or unashamed to ask questions if there was an explanation they had not understood. They are also actively discussing with friends and with lecturers when the matrix learning takes place within the group. In addition, students are also always trying hard to find a solution to matrix problems posed, either by lecturers or by tutors. The effort or motivation of finding this solution is demonstrated by using all media and learning resources both print and non print, as well 
as exploring the information they acquire during learning. A total of 96 people admitted very enthusiastic with learning matrix using peer tutoring model. So they are interested in attending lectures and engaging in meaningful group learning.

Piliani [3] explains that there is a relationship between confidence and motivation to learn. So, student motivation will emerge with confidence. When students have a high confidence, it will generate a good motivation to learn that is shown with an attitude of optimism, diligent, responsible and able to carry out something in accordance with the desired goals.

The intrinsic motivation indicator included in the second very high category is interesting with a percentage of $87 \%$. This student interest attitude is shown through serious concentration while studying the matrix, listening to the tutor's explanation in earnest, and never tired of following the matrix learning with peer tutoring techniques. As many as $57.6 \%(72)$ students pay close attention to every explanation submitted by the tutor. Students also admitted loving learning matrix with peer tutoring techniques.

In addition to interest, fun also has the same percentage of interest of $87 \%$, including very high category. The pleasure of students following the learning with peer tutoring techniques is evidenced by the high spirit of $60 \%$ of students in following the matrix learning with peer tutoring techniques. As many as $64 \%$ of students admitted very comfortable learning matrix with peer tutoring techniques.

The fourth intrinsic indicator of motivation is a necessity. The need in question is the student's need for matrix materials and innovative learning models that can foster motivation to learn. Percentage requirement of $84 \%$ included in the high category. This is because the response from the respondents is very good with regard to the importance of learning matrix for students. As many as $60(48 \%)$ of 125 students thought that studying matrix material was very important for them as the basic ingredients of application of matrix concept into programming and as many as 82 students $(66 \%)$ students felt loss if the matrix material was missed or in other words did not follow the learning matrix with peer tutoring learning.

A total of 78 students also stated that they always came on time because they wanted to study matrix material from beginning to end. And as many as 39 students also like to study the matrix independently to better understand than to hear the

explanation of the tutor. They repeat themselves and strengthen their understanding independently when the course is over. Motivation learning matrix with peer tutoring learning also appears in 57 students who said that learning matrix that they live really comes from within themselves respectively, not because of coercion let alone because the curriculum requires. And also as many as $77 \%$ of students stated that they really need to study the matrix with peer tutoring learning.

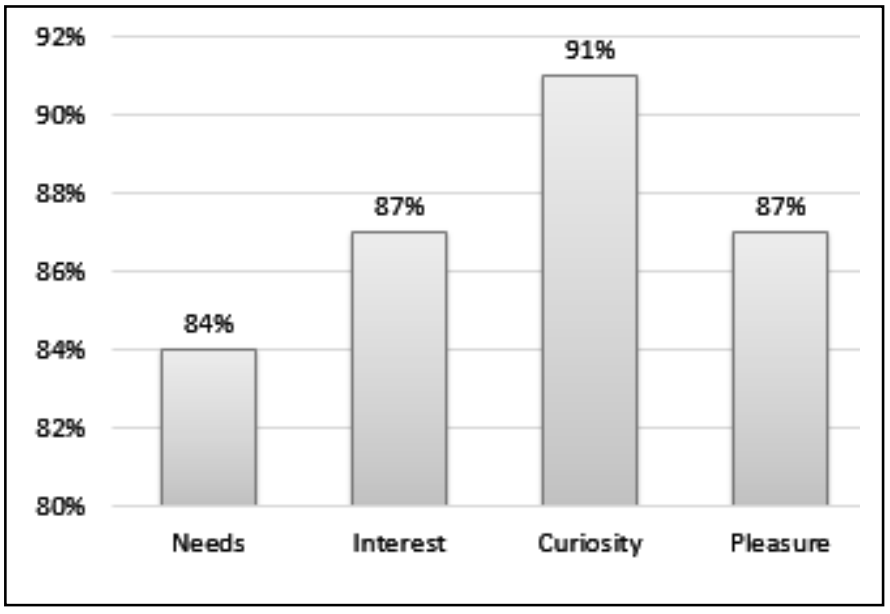

Fig. 1. Percentage of Student Intrinsic Motivation

Some research states that peer tutoring learning can improve the development of personal ability, motivation, and comfort of students in learning [4]. Arrand [5] in his research on the impact of peer tutoring on improving the skills of learners mentioned that there is a significant improvement in presentation skills. Peer tutoring has its own distinctive features that, if applied properly, will get significantly tangible and positive results.

\section{B. Extrinsic Motivation}

In addition to intrinsic motivation, sub indicators of extrinsic motivation include 1) clarity of learning objectives, and 2) rewards. Rewards become the highest extrinsic subindicator, $89 \%$ is a very high category, while the clarity of learning objective is included in a high category with the percentage of $80 \%$.

Students claim to be motivated to learn matrix because they want to gain new knowledge. Of course, learning techniques have a major impact on growing one of these motivations. New science will be more easily absorbed if the learning method used is interesting and does not make students bored. Praise from lecturers when students successfully solve a matrix problem is also one of the factors that can foster the spirit for students to complete other case studies presented, either by tutors or by lecturers.

Sujiantari [6] explains in his article that reward has significant effect on student learning motivation shown from tcount $>$ ttable $(4.156>1.982)$ or $p$-value $<\alpha(0.000<0.05)$. This finding is also in line with research conducted by Gina [7] and Susi [8] which states that the application of rewards can affect student learning motivation. Reward theoretically have an effect on to student's learning motivation. This is because the reward covers several aspects, namely the appreciation of educators (lecturers), praise, pats, smiles, sweet words, and gifts.

The students' understanding of the learning objectives of the matrix also contributes to the students to foster the spirit of learning matrix. Because clarity of learning objectives can give 
students an idea of what they will learn and goals to achieve. As many as $53.6 \%$ of students know the purpose of learning matrix, including how the application of matrix in everyday life, especially for a programmer.

Because the growth of motivation to learn can not be separated from the purpose of learning itself. Learning activities can be done well if students understand the goals to be achieved from their learning activities and consider these goals as needs that must be met. Thus, the clarity of learning objectives is very influential on the outcomes achieved by students. The better understanding of the goals to be achieved will be the greater the impulse within the students to achieve it [9].

Pangerti [10] in his research explains that peer tutor learning method has a significant influence on students' learning motivation in a math lesson. Another study by Sujiatmiani [11] also mentions the similar thing that peers tutoring method can improve science learning motivation by $11,78 \%$. Student motivation becomes one of the important points in the success of the learning process. Students who succeed in learning means have high intrinsic and extrinsic motivation. Enthusiastic attitude is shown from the beginning to the end of the learning through various activities and continues to increase during the learning process.

The importance of motivation is a major concern for lecturers, especially in Mathematics Engineering courses, Matrix Subject Matter. How lecturers determine the correct learning method that can grow and increase student motivation is homework for lecturers. Because not all learning methods and techniques can be applied to Matrix Subject Matter. And peer tutoring learning is one solution method that can be applied by a lecturer in learning matrix.

Student learning motivation increased seen from group activities in discussions, doing exercises, question and answer with tutors, and tournaments between groups. It can not be denied that the variation of teaching methods and strategies is very influential on student learning outcomes. Because students' learning outcomes are not only influenced by cognitive factors but also other factors such as motivation, interest, and learning strategies used by lecturers [12]. Thus, peer tutoring learning is very appropriately applied in learning mathematics, because it can train students to deliver material in front of the class and for student participants can explore their understanding by asking the tutor. Successful application of learning methods can certainly improve students' learning motivation, resulting in increased student learning outcomes.

Back to the concept of SCL or often called Student Centered Learning is learning that focuses on students as learners. Students are given the opportunity to experiment, experience their own learning, to solve problems. The lecturer does not actually play the role of the facilitator who directs the learning objectives. Every student can not be beaten flat or equal, because they have the characteristics and learning styles of each. However, with peer tutoring learning, different learning styles can be incorporated because there are discussions, reading, observing, arguing, explaining, and other activities that adapt each student's learning style. The combination of learning styles with motivation in learning contributes to student understanding. This opinion is supported by the theory of Olivos [13] in his research proves that there is a significant relationship between learning styles and motivation to the understanding of learners.

\section{CONCLUSION}

Based on the results and discussion, it can be concluded that the percentage of student motivation in learning matrix of $86 \%$, belong to the category very well. The level of student motivation is measured based on 2 indicators, namely intrinsic motivation and extrinsic motivation. The percentage of intrinsic motivation is $87 \%$ and extrinsic motivation is $85 \%$, both of which fall into the very high category. Sub indicators of intrinsic motivation include need, interest, curiosity, and pleasure. Percentage of each sub indicator of intrinsic motivation, ie 1) needs of $84 \%, 2$ ) interest of $87 \%, 3$ ) curiosity of $91 \%$, and 4) pleasure by $87 \%$.

The high percentage of sub indicators of curiosity is caused by the curiosity of the students who are very high as well. Curiosity is seen from the liveliness of asking, discussing, finding solutions to problems, and enthusiastic listening tutor explanation. Students feel confident or not embarrassed to ask questions if there is an explanation they have not understood. They are also actively discussing with friends and with lecturers when the matrix learning takes place within the group.

Extrinsic motivation sub indicators include 1) clarity of learning objectives, and 2) rewards. Rewards become the highest extrinsic sub-indicator, $89 \%$ is a very high category, while the clarity of learning objective is included in a high category with the percentage of $80 \%$.

Students claim to be motivated to learn matrix because they want to gain new knowledge. Of course, learning techniques have a major impact on growing one of these motivations. New science will be more easily absorbed if the learning method used is interesting and does not make students bored. Praise from lecturers when students successfully solve a matrix problem is also one of the factors that can foster the spirit for students to complete other case studies presented, either by tutors or by lecturers.

\section{REFERENCES}

[1] Djamarah, Syaiful Bahri. (2008). Psikologi Belajar. Jakarta: Rineka Cipta.

[2] Sardiman. 2011. Interaksi dan Motivasi Belajar-Mengajar. Jakarta: Rajawali Pers.

[3] Piliani, Made. 2014. Korelasi antara Kepercayaan Diri dengan Motivasi Belajar pada Siswa SMP di Mataram, (Online), http://www.ejournal.pkpsmikipmat aram.org/index.php/jiim/article, diakses tanggal 21 November 2016

[4] Hammond, J., Bithell, C., Jones, L. and Bidgood, P. 2010. A First Year Experience of Student-directed Peer-assisted Learning: Active Learning in Higher Education.

[5] Arrand, Karen. 2014. Peer Tutoring, (Online), https://www.beds.ac.uk/jpd/volume-4-issue-1/peer-tutoring, diakses tanggal 21 November 2016.

[6] Sujiantari, Ni Kadek. 2016. Pengaruh Reward dan Punishment terhadap Motivasi Belajar Siswa dalam Pembelajaran IPS. Jurnal Jurusan Pendidikan Ekonomi (JJPE), 7(2): 01-10. 
[7] Gina Rahmadiyanti. 2013. Pengaruh Reward dan Punishment Terhadap Motivasi Belajar Pada Kompetensi Dasar Mencatat Transaksi Dokumen ke dalam Jurnal Umum. Skripsi tidak diterbitkan, Bandung: UPI.

[8] Susi Andriani. 2013. Penerapan Reward Sebagai Upaya Peningkatan Motivasi Belajar Siswa dalam Pembelajaran IPS Kelas III A Di MIN Tempel Ngaglik Sleman. Skripsi tidak diterbitkan, Yogyakarta: UIN Sunan Kalijaga.

[9] Lafianto, Putaris. 2012. Motivasi dan Persepsi Siswa tentang Kelengkapan Fasilitas Praktik serta Pengaruhnya terhadap Prestasi Belajar Siswa Kelas X SMKN 2 Yogyakarta. Skripsi tidak diterbitkan, Yogyakarta: UNY

[10] Pangerti, Budi. 2015. Pengaruh Metode Pembelajaran Tutor Sebaya terhadap Motivasi Belajar, Minat Belajar, dan Hasil Belajar Matematika Kelas XI Ilmu Alam MAN Model Sorong. Jurnal Ilmu Pendidikan Indonesia, 3(1): 30-49.

[11] Sujatmiani. 2015. Penggunaan Metode Peer Tutoring dengan Kassitu untuk Meningkatkan Motivasi dan Hasil Belajar IPA Fisika. JRKPF UAD, 2(2): 46-49.

[12] Fang, Ning. 2014. Correlation Between Students' Motivated Strategies for Learning and Academic Achievement in an Engineering Dynamics Course. Global Journal of Engineering Education, 16(1): 06-12. 